\title{
Role of the Low Density Lipoprotein Receptor in the Flux of Cholesterol Through the Plasma and Across the Tissues of the Mouse
}

\author{
Yasunori Osono, ${ }^{\star}$ Laura A. Woollett, ${ }^{*}$ Joachim Herz, ${ }^{\ddagger}$ and John M. Dietschy* \\ Departments of $*$ Internal Medicine and ${ }^{\ddagger}$ Molecular Genetics, University of Texas Southwestern Medical Center at Dallas, \\ Dallas, Texas 75235
}

\begin{abstract}
These studies were undertaken to quantify cholesterol balance across the plasma space and the individual organs of the mouse, and to determine the role of the low density lipoprotein receptor (LDLR) in these two processes. In the normal mouse (129 Sv), sterol was synthesized at the rate of $153 \mathrm{mg} / \mathrm{d}$ per $\mathrm{kg}$ body weight of which $78 \%$ occurred in the extrahepatic tissues while only $22 \%$ took place in the liver. These animals metabolized 7.1 pools of LDL-cholesterol (LDL-C) per day, and $79 \%$ of this degradation took place in the liver. Of this total turnover, the LDLR accounted for $88 \%$ while the remaining $12 \%$ was receptor independent. $91 \%$ of the receptor-dependent transport identified in these animals was located in the liver while only $38 \%$ of the receptor-independent uptake was found in this organ. When the LDLR was deleted, the LDL-C production rate increased 1.7-fold, LDL-C turnover decreased from 7.1 to $0.88 \mathrm{pools} / \mathrm{d}$, and the plasma LDL-C level increased 14fold, from 7 to $101 \mathrm{mg} / \mathrm{dl}$. Despite these major changes in the circulating levels of LDL-C, however, there was no change in the rate of cholesterol synthesis in any extrahepatic organ or in the whole animal, and, further, there was no change in the steady-state cholesterol concentration in any organ. Thus, most extrahepatic tissues synthesize their daily sterol requirements while most LDL-C is returned directly to the liver. Changes in LDLR activity, therefore, profoundly alter the plasma LDL-C concentration but have virtually no affect on cholesterol balance across any extrahepatic organ, including the brain. (J. Clin. Invest. 1995. 95:1124-1132.) Key words: plasma cholesterol • liver LDL receptors • low density lipoprotein • cholesterol synthesis • knockout mouse
\end{abstract}

\section{Introduction}

Lipoproteins containing apoprotein B (apoB) apparently have evolved principally as vehicles for moving triacylglycerol and other hydrophobic lipids, e.g., fat soluble vitamins, between major organ systems $(1,2)$. In virtually all species the principle

Address correspondence to John M. Dietschy, M.D., Department of Internal Medicine, University of Texas Southwestern Medical Center at Dallas, Dallas, TX 75235-8887. Phone: 214-648-2150; FAX: 214-6489761.

Received for publication 18 July 1994 and in revised form $11 \mathrm{No}$ vember 1994.

J. Clin. Invest.

(c) The American Society for Clinical Investigation, Inc.

$0021-9738 / 95 / 03 / 1124 / 09 \$ 2.00$

Volume 95, March 1995, 1124-1132
apoB protein in the chylomicron $(\mathrm{CM})^{1}$ particle is apoB48, a truncated product of the apoB gene that lacks the sequences necessary to bind to the low density lipoprotein receptor (LDLR) (3-5). In contrast, in most species the very low density lipoprotein (VLDL) particle contains the full-length transcript, apoB100, that can interact with this receptor (6). In a few species like the rat and mouse, however, this particle contains a mixture of apoB48 and apoB100 (7-10). At least two separate receptors are involved in removing the remnants of these apoBcontaining particles from the plasma $(11,12)$. One of these is the low density lipoprotein receptor related protein (LRP) that is located principally in the liver (13-15) and that can bind a variety of ligands including apoprotein $\mathrm{E}$ (apoE), $\alpha_{2}$-macroglobulin, lipoprotein lipase and plasminogen activators (1619). Data from several sources suggest that this receptor, acting in concert with the LDLR, is responsible for hepatic uptake of the apoE/apoB48-containing remnants of the $\mathrm{CM}(15,20,21)$. In contrast, the LDLR is capable of binding lipoproteins containing apoE or apoB 100 (22). Approximately $70-80 \%$ of such receptor activity is also found in the liver of all species, including humans, in which data are available (23). This receptor plays the major role in removing from the plasma the remnant products of VLDL metabolism including the apoB100/apoEcontaining VLDL remnants $(24,25)$ and the apoB100containing low density lipoprotein (LDL) particles $(23,24$, 26-28).

Epidemiological data clearly support the view that the risk of developing atherosclerotic disease is determined, in a major way, by the steady-state concentration of cholesterol in the plasma carried in LDL (LDL-C) (29-32). This steady-state LDL-C concentration is determined by four separate rate constants that include the LDL-C production rate $\left(J_{t}\right)$, the maximal rate of LDL-C transport that can be achieved when all LDL receptors are occupied $\left(J^{\mathrm{m}}\right)$, the functional affinity of the LDL for its receptor $\left(K_{\mathrm{m}}\right)$, and the rate of LDL-C uptake by a process that apparently does not depend upon the $\operatorname{LDLR}(\mathrm{P})(33,34)$. This LDLR-independent component of LDL-C clearance has been identified in every species that has been examined, and accounts for a significant percentage of LDL-C clearance in the rat $(25 \%)$, hamster $(27 \%)$, guinea pig $(22 \%)$, rabbit $(28 \%)$, and human $(42 \%)(23,35-39)$. Whether this receptor-independent clearance involves LRP or other, as yet unrecognized, processes is currently not known.

Much, however, is understood about the regulation of the other rate constants that determine the steady-state LDL-C level. For example, genetic alterations that lower $J^{\mathrm{m}}$ to essentially zero

1. Abbreviations used in this paper: $\mathrm{CM}$, chylomicron; LDL-C, cholesterol carried in LDL; $\mathrm{LDLR}^{+1+}$ and $\mathrm{LDLR}^{-1-}$, mice homozygous for the presence or absence of the LDLR gene; LDLR, low density lipoprotein receptor; LRP, low density lipoprotein receptor related protein; $\mathrm{mhLDL}$ $\mathrm{C}$, methylated human LDL-C. 
$(38,39)$ or elevate $K_{\mathrm{m}}(40-42)$ lead to predictable elevations in the LDL-C level (43). Furthermore, environmental factors such as the dietary intake of saturated fatty acids with 12,14 , or 16 carbon atoms cause suppression of $J^{\mathrm{m}}$ and also elevate the LDLC level $(44,45)$, while intake of the $18: 1(9 c)$ fatty acid or soluble fiber increases receptor activity and lowers the plasma LDL-C level $(46,47)$. In many of these studies, however, the production rate term changes in a reciprocal manner with respect to $J^{\mathrm{m}}$. When LDL receptor activity is reduced, for example, by either genetic or environmental manipulations, LDL-C production invariably increases and contributes in a major way to the marked increase observed in the plasma LDL-C concentration under these conditions $(37-39,48)$. One major reason for this reciprocal relationship is presumably the specificity of the clearance process in the liver. When hepatic LDLR activity is high, a large proportion of the apoB100/apoE-containing VLDL remnants is presumably taken up by this receptor and so is not converted to LDL-C, i.e., $J_{\mathrm{t}}$ is low. With reduction in $J^{\mathrm{m}}$, however, a greater proportion of these remnants is metabolized to LDL, and LDL-C production necessarily increases.

The mouse, in which specific enzymes, transporters and apoproteins can be either deleted or overexpressed, offers a powerful model for examining these processes and for further elucidating changes in the quantitative physiology of lipoproteins, in general, and of LDL-C, in particular. However, the characteristics of cholesterol and LDL-C physiology in the normal mouse have not yet been described in detail although, as in the rat, these processes are thought to vary considerably from those seen in higher species, including several primates (23). Furthermore, no reports have yet appeared on how deletion of the LDLR alters cholesterol balance across the individual tissues of this species. The current studies were undertaken, therefore, for four reasons. First, preliminary investigations were undertaken to establish that the quantitative methods available in larger animals for characterizing cholesterol and LDL-C metabolism could be applied to a small rodent like the mouse. Second, measurements were made of the role of each organ in this species for cholesterol synthesis and receptor-dependent and receptor-independent LDL-C removal from the plasma. Third, a comparison was made of the effects of gender on steady-state tissue cholesterol contents and synthetic rates. Finally, the effect of deleting the LDLR on these steady-state cholesterol contents and synthetic rates, and on the LDL-C production and transport rates were defined.

\section{Methods}

Animals and diets. These studies were undertaken using mice in which the LDL receptor had been disrupted by homologous recombination using animals with the inbred $129 \mathrm{~Sv}$ background (27). To obtain inbred $129 \mathrm{~Sv} \mathrm{LDLR}^{-1-}$ mice, chimeric founder mice were crossed with wild type $129 \mathrm{~Sv}$ female mice. $\mathrm{LDLR}^{+/-}$offspring $\left(\mathrm{F}_{1}\right.$ generation $)$ were identified by Southern blot analysis and propagated in brother/sister matings to obtain homozygous $\mathrm{LDLR}^{-1-}$ animals. All $\mathrm{LDLR}^{-1-}$ mice used in these experiments were descendants of these homozygous LDL receptor deficient $F_{2}$ generation mice.

In this study, a comparison was made of cholesterol metabolism in male and female animals using only the wild-type mouse (LDLR ${ }^{+1+}$ ) and animals that were homozygous for disruption of the LDLR gene $\left(\mathrm{LDLR}^{-1-}\right)$. Before use, all animals were housed in colony cages in a room with light cycling, and temperature and humidity control. The animals were subjected to $12 \mathrm{~h}$ of light and $12 \mathrm{~h}$ of darkness throughout this period, and all measurements were made during the mid-dark phase of the light cycle. Before and during all studies, the mice were maintained on a low cholesterol diet consisting of Wayne Lab Blox (Allied Mills, Chicago, IL) which, by direct analysis, contained $0.24 \mathrm{mg}$ of cholesterol and $50 \mathrm{mg}$ of total lipid per $\mathrm{g}$ of diet. It was experimentally determined that these mice ate an average of $4.6 \mathrm{~g} / \mathrm{d}$ of this diet so that each animal had a mean daily intake of $1.10 \mathrm{mg}$ of dietary cholesterol or $40 \mathrm{mg} / \mathrm{d}$ per $\mathrm{kg}$ of body weight.

Plasma and tissue cholesterol concentrations. Blood samples were obtained by exsanguinating the animal through the inferior vena cava. The concentration of cholesterol in the various plasma lipoprotein fractions was obtained by simultaneously centrifuging samples after adjusting the density to 1.020 and $1.063 \mathrm{~g} / \mathrm{ml}$. These lipoprotein samples were then saponified, and the cholesterol concentration was determined by gas/liquid chromatography (48). The major organs were removed from the animal, weighed, and saponified. The remaining carcass, which was composed primarily of skeleton, muscle and adipose tissue, was also saponified. The cholesterol content of these tissue samples was determined in triplicate (49). Aliquots of the liver were also analyzed for their content of unesterified and esterified cholesterol using silicic acid/celite columns (50).

Cholesterol synthesis in the organs in vivo. Rates of cholesterol synthesis were measured in vivo at the mid-dark phase of the light cycle. Each animal was injected intraperitoneally with $20 \mathrm{mCi}$ of $\left[{ }^{3} \mathrm{H}\right]$ water contained in $100 \mu \mathrm{l}$ of isotonic saline solution $(49,51,52)$. One hour later the animal was anesthetized and $800 \mu \mathrm{l}$ of blood was aspirated from the inferior vena cava. The organs were removed and saponified, and the digitonin precipitable sterols were isolated as described previously (52). The specific activity of the $\left[{ }^{3} \mathrm{H}\right]$ water in the plasma was determined in triplicate from the blood sample. The rates of sterol synthesis in each of the organs in the live animal were then calculated as the nmol of $\left[{ }^{3} \mathrm{H}\right]$ water incorporated into the digitonin precipitable sterols per $\mathrm{g}$ of tissue or per whole organ ( $\mathrm{nmol} / \mathrm{h}$ per gram or organ) (51). The rate of cholesterol synthesis in the whole animal was calculated as the sum of the rates of synthesis in all of the organs and carcass. Previous work has established that $\sim 25 \mu \mathrm{g}$ atoms of hydrogen from water are incorporated into each $\mu \mathrm{mol}$ of newly synthesized cholesterol $(52,53)$.

Isolation and radiolabeling of lipoprotein fractions. In the studies designed to measure the rate of LDL-C transport, lipoproteins were isolated from mouse, human and sheep plasma. The human plasma was collected from normal lipidemic volunteers. Mouse plasma was harvested from both male and female, LDLR knockout mice (129Sv $\times$ C57BL/ 6 hybrids) maintained on a low cholesterol rodent diet. Similarly, the LDL fraction was isolated from sheep plasma taken from animals maintained on a low cholesterol intake. In all cases the LDL fraction was isolated in the density range of $1.020-1.055 \mathrm{~g} / \mathrm{ml}$ by preparative ultracentrifugation, and all fractions contained essentially only apoB. Aliquots of each of these fractions were then labelled with either ${ }^{125}$ I-tyramine cellobiose or with ${ }^{131} \mathrm{I}(49,54)$. In some experiments, a portion of the labelled human LDL was further processed by reductive methylation (mhLDL-C) $(36,38,55,56)$. All of these lipoprotein preparations were then dialyzed extensively against $0.9 \% \mathrm{NaCl}$ solution and passed through a $0.45 \mu \mathrm{m}$ Millex-HA filter (Millipore Products, Bedford, MA) immediately prior to injection into the recipient experimental animals. All fractions were used within $24 \mathrm{~h}$ of preparation.

LDL-C transport into the mouse tissues in vivo. Rates of tissue LDL-C clearance were determined in vivo using a primed-continuous infusion of ${ }^{125}$ I-tyramine cellobiose-labeled LDL through an intravenous catheter secured into a tail vein (35). At the mid-dark phase of the light cycle, the mouse was lightly anesthetized with diethyl ether and a Micro Teflon ${ }^{\otimes}$ PTFE tubing (i.d. 0.008 inches) (Cole-Parmer Instrument Co., Chicago, IL) was inserted into a lateral tail vein using a half-ground 21-gauge needle. The catheter was fixed in place and attached to a syringe on a micro-infusion pump (B. Braun, Melsungen, Germany). Each animal was then given a bolus injection of the radiolabeled LDL preparation followed by a continuous infusion of the same preparation at a rate calculated to maintain a constant specific activity in the plasma throughout the 4-h infusion period. In preliminary experiments the ratio 
of the radioactivity in the bolus to that in the infusion necessary to maintain this constant specific activity was determined in both the $\mathrm{LDLR}^{+/+}$and $\mathrm{LDLR}^{-1-}$ animals. 10 min before terminating the 4-h infusion, a bolus of the ${ }^{131} \mathrm{I}$-labeled LDL was administered through the same catheter to the animal $(33,35,36,38)$. Exactly $10 \mathrm{~min}$ after the second bolus injection, and $4 \mathrm{~h}$ after beginning the infusion, the animal was again anesthetized and blood was drawn from the inferior vena cava. Each of the organs was removed, rinsed, weighed, and assayed for its content of ${ }^{125} \mathrm{I}$ and ${ }^{131} \mathrm{I}$. These numbers were then used to calculate the rate of clearance of the LDL preparation into each of the organs and in the whole animal $(45,49)$. These clearance rates are expressed as the $\mu \mathrm{l}$ of plasma cleared of its LDL content per h per $\mathrm{g}$ of tissue or per whole organ $(\mu \mathrm{l} / \mathrm{h}$ per $\mathrm{g}$ or $\mu \mathrm{l} / \mathrm{h}$ per organ). The rate of LDL clearance in the whole animal was calculated as the sum of the rates of clearance in all of the organs, including the carcass.

Calculations. From these various experimental measurements, a number of other data could be derived. From the rates of $\left[{ }^{3} \mathrm{H}\right]$ water incorporation into digitonin precipitable sterols by the whole animal, it was possible to calculate the rate of whole mouse sterol synthesis expressed as the mg of cholesterol synthesized per day per $\mathrm{kg}$ of the body weight $(\mathrm{mg} / \mathrm{d}$ per $\mathrm{kg}$ ). From the rate of whole mouse LDL-C clearance ( $\mu \mathrm{l} / \mathrm{h}$ per mouse), the daily fractional catabolic rate of LDL (pools/ day) could be calculated since the plasma volume in the mouse equals $47 \mathrm{ml} / \mathrm{kg}$ body weight (57). In the steady state, the rate of LDL-C clearance in the whole animal must equal the LDL-C production rate so that this latter value could be calculated as the product of the whole mouse clearance rate times the plasma LDL-C concentration (23). The data in all of these experiments are presented as mean values \pm 1 SEM. The Student's unpaired $t$ test was used $(P<0.05)$ to compare the various sets of data. In the figures and tables, a value that is significantly different at this level from its appropriate control value in the $\mathrm{LDLR}^{+/+}$ animals is indicated by an asterisk.

\section{Results}

After feeding to steady state, the male $\mathrm{LDLR}^{+1+}$ and $\mathrm{LDLR}^{-1}$ mice weighed $27 \pm 1 \mathrm{~g}$ while the females weighed $23 \pm 1 \mathrm{~g}$. The distribution of body mass among the various organs was essentially the same, and there was no difference in the weight of any organ in the $\mathrm{LDLR}^{+1+}$ and $\mathrm{LDLR}^{-1-}$ animals, male or female. There were, however, significant differences in the levels of cholesterol in the various lipoprotein fractions (Fig. 1). Under conditions where dietary cholesterol intake equaled 40 $\mathrm{mg} / \mathrm{d}$ per $\mathrm{kg}$, the LDL-C concentration was 14-fold higher in the $\mathrm{LDLR}^{-1-}$ animals than in the control mice. In both the male and female animals the concentration of HDL-C was higher in the receptor deficient groups, and there were also small increases in the concentration of cholesterol in lipoproteins with a density $<1.020 \mathrm{~g} / \mathrm{ml}(27)$.

The effect of deleting LDL receptor activity on the tissue cholesterol concentration was next investigated. As illustrated in Fig. 2, the level of cholesterol in the various organs varied from $\sim 14 \mathrm{mg} / \mathrm{g}$ in brain to $\sim 1.3 \mathrm{mg} / \mathrm{g}$ in heart muscle and carcass. These levels were similar in the male and female mice with the exception of the adrenal gland where the concentration equaled $7.7 \pm 0.8 \mathrm{mg} / \mathrm{g}$ in the male $\mathrm{LDLR}^{+/+}$animal but $30.3 \pm 3.6 \mathrm{mg} / \mathrm{g}$ in the female. The concentration in the liver of the females also was slightly higher $(3.4 \pm 0.5 \mathrm{mg} / \mathrm{g})$ than in the males $(2.2 \pm 0.1 \mathrm{mg} / \mathrm{g})$. More importantly, however, there was no decrease in the concentration of sterol in any tissue of the LDLR ${ }^{-1-}$ animal. For example, the level of cholesterol in the brain equaled $14.1 \pm 0.5$ and $14.0 \pm 0.5 \mathrm{mg} / \mathrm{g}$ in the male $\mathrm{LDLR}^{+1+}$ and $\mathrm{LDLR}^{-1-}$ animals, respectively. Furthermore, the concentration of cholesterol in the adrenal glands was

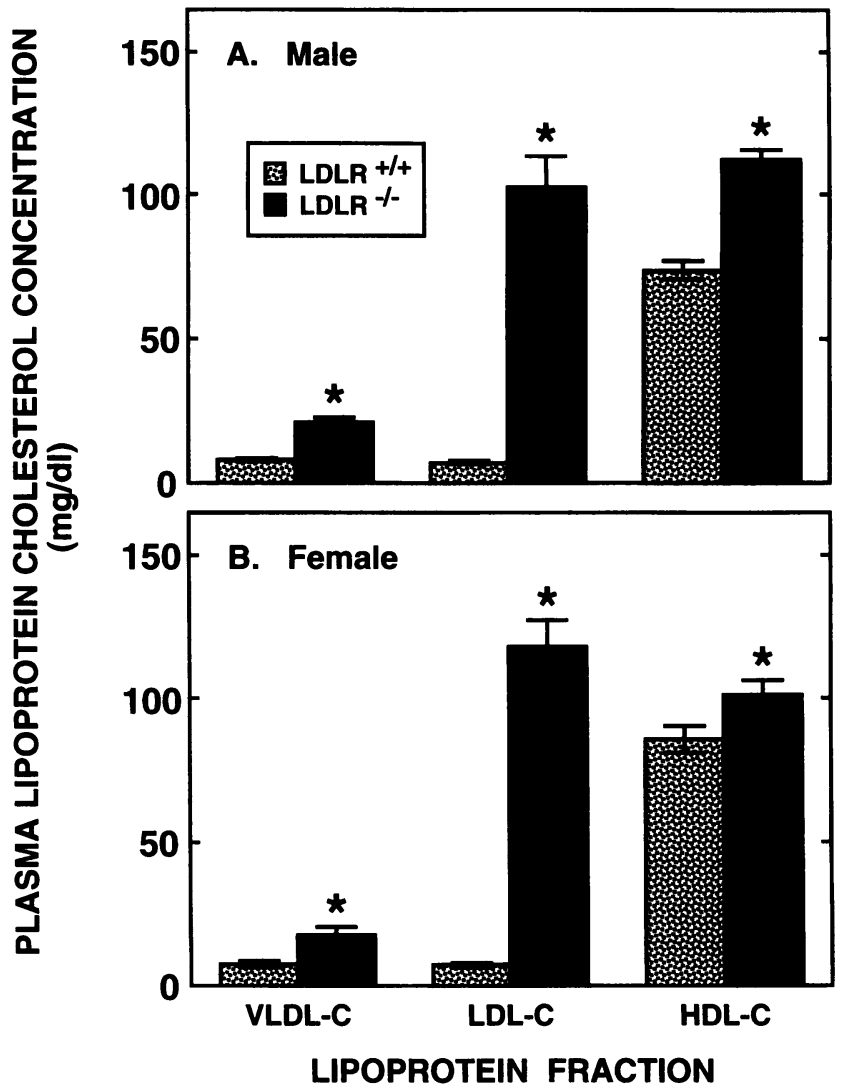

Figure 1. Concentration of cholesterol carried in lipoprotein fractions of different density in the plasma of male $(A)$ and female $(B)$ LDLR $^{+1+}$ and LDLR $^{-1-}$ mice maintained on low cholesterol rodent diet. Three groups of lipoproteins were separated from the plasma of these animals and are designated VLDL-C $(<1.020 \mathrm{~g} / \mathrm{ml})$, LDL-C $(1.020-1.063 \mathrm{~g} / \mathrm{ml})$ and HDL-C $(>1.063 \mathrm{~g} / \mathrm{ml})$. These values represent the means \pm 1 SEM for plasma samples obtained from five animals in each group. $*$ Value is significantly different from that in the LDLR $^{+/+}$animals.

slightly higher in the receptor deficient mice in both the male $(9.8 \pm 2.4$ vs. $7.7 \pm 0.8 \mathrm{mg} / \mathrm{g})$ and female $(39.8 \pm 9.0 \mathrm{vs}$. $30.3 \pm 3.6 \mathrm{mg} / \mathrm{g}$ ) animals. In addition, the concentration of cholesteryl esters in the liver of the male $(0.9 \pm 0.1$ vs. $0.5 \pm 0.1$ $\mathrm{mg} / \mathrm{g})$ and female $(2.0 \pm 0.2 \mathrm{vs} .1 .1 \pm 0.2 \mathrm{mg} / \mathrm{g}) \mathrm{LDLR}^{-1-}$ animals was nearly twofold higher than in the corresponding LDLR $^{+1+}$ animal, a finding that has also been reported in the homozygous WHHL rabbit (58).

From these data and the weights of the various organs, it was possible to determine the absolute size and distribution of the cholesterol pools in these four groups of animals. The pool of sterol in the male $\mathrm{LDLR}^{+/+}$mice equaled $49.6 \pm 4.9 \mathrm{mg}$ and in the $\mathrm{LDLR}^{-1-}$ animals was $51.2 \pm 3.1 \mathrm{mg}$. There was also no significant difference in the females. The distribution of these sterol pools was virtually identical in the male and female animals. About $50 \%$ of the pool was located in the carcass while the skin $(\sim 15 \%)$, brain $(\sim 12 \%)$, liver $(6-7 \%)$, and other tissues contained much smaller percentages of the total body pools. Thus, deletion of LDL receptor activity had no demonstrable effect on the steady-state concentration of cholesterol in any tissue or on the distribution of the total body pool of sterol among the various organ systems in either the male or female animals. 


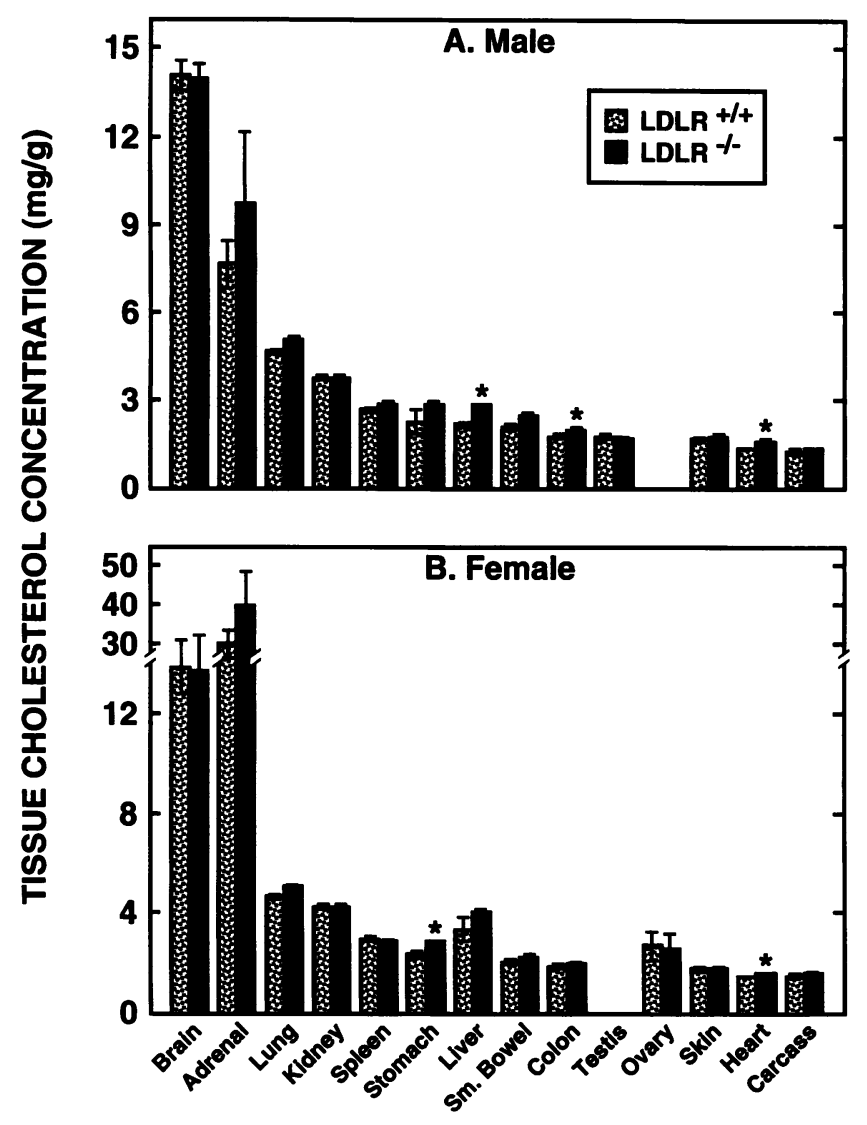

Figure 2. Concentration of cholesterol in the tissues of the male $(A)$ and female $(B)$ LDLR $^{+1+}$ and LDLR ${ }^{-1-}$ mice. These animals were $\sim 3$ mo old and weighed 19-30 g. Each organ was dissected and weighed, and the concentration of cholesterol was determined. These values are expressed as $\mathrm{mg} / \mathrm{g}$ wet weight of tissue. The tissue designated carcass contained all of the remaining organs left at the end of the dissection and consisted primarily of bone, muscle, and fat. Means \pm 1 SEM for five animals in each group are shown. * Value is significantly different from that in the $\mathrm{LDLR}^{+/+}$animal.

This finding implied either that receptor-dependent LDL-C transport played little role in the maintenance of cholesterol pools in the extrahepatic organs or that there were increases in in situ synthesis that fully compensated for loss of this uptake of plasma sterol. Therefore, rates of cholesterol synthesis were measured in vivo in these four groups of animals. As is apparent in Fig. 3, in the control mice, liver manifested the highest rates of synthesis and these rates were similar in the $\mathrm{LDLR}^{+1+}$ female $(1348 \pm 320 \mathrm{nmol} / \mathrm{h}$ per gram) and male $(1140 \pm 225 \mathrm{nmol} / \mathrm{h}$ per gram). The extrahepatic organs in both sexes had lesser rates of sterol synthesis that varied from $530-670 \mathrm{nmol} / \mathrm{h}$ per gram in various parts of the gastrointestinal tract to $<60 \mathrm{nmol} /$ $h$ per gram in heart and carcass. In particular, the ovaries, adrenal glands and brain synthesized cholesterol at the intermediate rates of $238,280-458$, and $95-109 \mathrm{nmol} / \mathrm{h}$ per gram, respectively. Most importantly, however, deletion of receptordependent LDL-C transport in the animals did not cause an increase in de novo synthesis in any tissue including the ovaries, adrenal glands and brain.

Thus, as shown in Fig. $4 \mathrm{~A}$, the rates of sterol synthesis in the whole mouse equaled $5737 \pm 340$ and $5840 \pm 358 \mathrm{nmol} / \mathrm{h}$ in the $\mathrm{LDLR}^{+/+}$and $\mathrm{LDLR}^{-1-}$ male animals, respectively. These
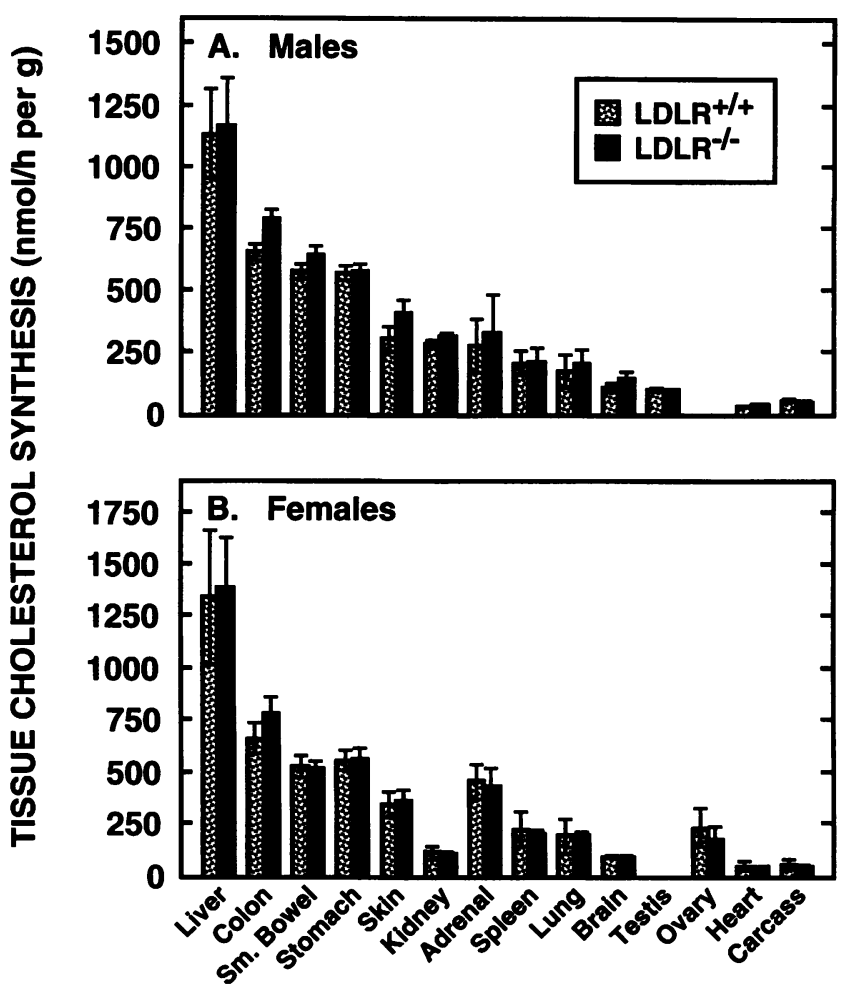

Figure 3. Cholesterol synthetic activity in the tissues of the male $(A)$ and female $(B)$ LDLR $^{+1+}$ and LDLR $^{-1-}$ mice. These animals were $\sim 3$ mo old and weighed 20-33 g. Rates of synthesis were determined in vivo and are expressed as the nmol of $\left[{ }^{3} \mathrm{H}\right]$ water incorporated into digitonin precipitable sterols per $g$ of tissue. Mean values \pm 1 SEM for 4-8 animals are shown.

values correspond to rates of cholesterol synthesis equal to $\sim 153$ and $162 \mathrm{mg} / \mathrm{d}$ per $\mathrm{kg}$ body weight, respectively, in the two groups. Slightly lower rates were seen in the females (Fig. $4 C$ ). The skin accounted for the largest fraction of this whole animal synthetic activity (Fig. $4, B$ and $D$ ), while synthesis in the liver equaled $22-26 \%$ of whole animal synthesis in both the male and female, LDLR $^{+/+}$and LDLR $^{-1-}$ animals. Other important organs included the tissues of the carcass, small bowel, colon, and stomach, and again, there was no significant difference seen among any of the tissue compartments with respect to their contribution to whole animal cholesterol synthesis.

Studies were next undertaken, therefore, to quantitate the magnitude of LDL-C transport into these same tissues by both receptor-dependent and receptor-independent mechanisms. These investigations were carried out in only male animals since, in the studies reported thus far, there were essentially no differences in the metabolism of cholesterol in the male and female animals. Before undertaking these measurements, however, it was first necessary to determine what preparations of LDL could be used to accurately assess rates of LDL-C transport in the live mouse by the receptor-dependent and -independent pathways. In an initial experiment, total LDL-C clearance was measured in male $\mathrm{LDLR}^{+/+}$animals using LDL harvested from mouse, human and sheep plasma. As is apparent in Table I, the liver and adrenal gland took up heterologous LDL-C at rates that were either lower (human LDL) or higher (sheep LDL) than the rates of clearance of homologous mouse LDL. These 

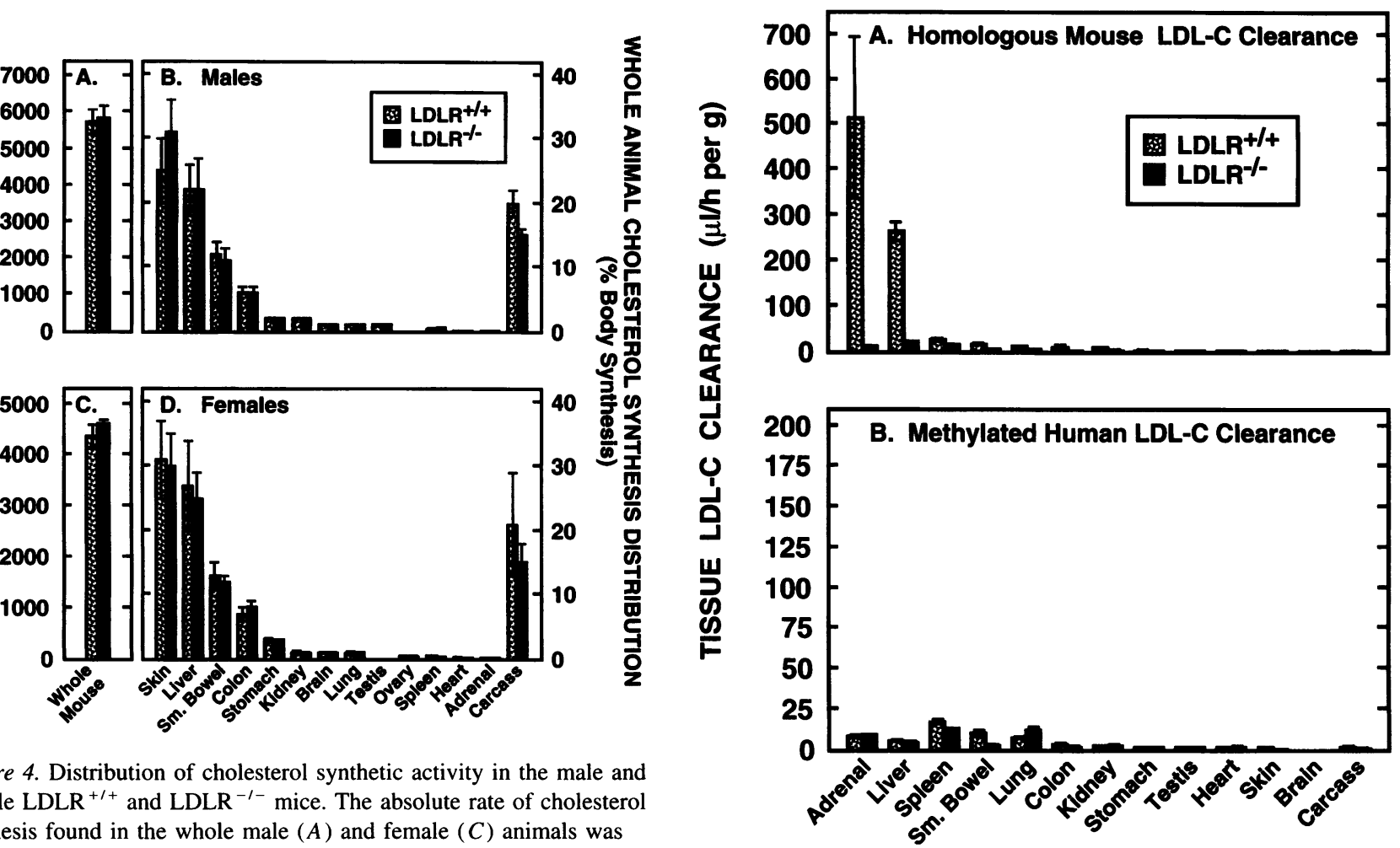

Figure 4. Distribution of cholesterol synthetic activity in the male and female LDLR $^{+/+}$and LDLR $^{-1-}$ mice. The absolute rate of cholesterol synthesis found in the whole male $(A)$ and female $(C)$ animals was calculated from the data in Fig. 3. In addition, the relative distribution of this synthetic activity among the various organs of the male $(B)$ and female $(D) \mathrm{LDLR}^{+/+}$and $\mathrm{LDLR}^{-1-}$ animals is also shown. Mean values \pm 1 SEM for 4-8 animals in each group are shown.

differences were less apparent in spleen and small bowel where uptake is mediated primarily by receptor-independent transport.

A second experiment was performed to determine if methylation of human LDL blocked entirely the ability of the mouse LDLR to transport this derivatized heterologous LDL preparation (mhLDL), as is true in some other species (33). As also seen in Table I, in the LDLR $^{+/+}$animal mouse LDL-C was cleared by the liver and adrenal gland at very high rates while the mhLDL-C preparation was taken up at velocities of $<5 \%$

Table I. Rates of $L D L-C$ and Methylated LDL-C Clearance in the Male LDLR ${ }^{+/+}$Mouse

\begin{tabular}{lcccc}
\hline Type of LDL-C & Liver & Adrenal gland & Spleen & Small bowel \\
\hline \multicolumn{4}{c}{$\mu / h$ per gram } \\
Mouse & $263 \pm 18$ & $333 \pm 42$ & $25 \pm 2$ & $18 \pm 3$ \\
Human & $111 \pm 11^{*}$ & $275 \pm 58$ & $25 \pm 4$ & $19 \pm 2$ \\
Sheep & $668 \pm 47^{*}$ & $632 \pm 84^{*}$ & $47 \pm 3^{*}$ & $23 \pm 3$ \\
mhLDL-C & $6 \pm 1^{*}$ & $8 \pm 1^{*}$ & $17 \pm 2^{*}$ & $11 \pm 2^{*}$ \\
& & & &
\end{tabular}

LDL-C was isolated from the plasma of the mouse, human, and sheep and conjugated to radiolabeled tyramine cellobiose as described in Methods. A portion of the human LDL-C was also reductively methylated $(m h L D L-C)$. The rates of transport of each of the LDL-C preparations into four organs of the $\mathrm{LDLR}^{+/+}$mouse were then measured. The data represent means \pm 1 SEM for 3 (sheep), 4 (human), 10 (mouse), or 3 $(\mathrm{mhLDL}-\mathrm{C})$ recipient animals. $*$ Value significantly different from that seen with mouse LDL-C.

Figure 5. Rates of clearance of homologous mouse LDL-C $(A)$ or methylated human LDL-C $(B)$ by the tissues of the male LDLR $^{+/+}$and $\mathrm{LDLR}^{-1-}$ animals. These rates are expressed as the microliter of plasma cleared of its LDL-C content each $\mathrm{h}$ per gram of tissue. The data in $A$ represent mean values \pm 1 SEM for $10 \mathrm{LDLR}^{+1+}$ and $9 \mathrm{LDLR}^{-1-}$ animals. In $B$ there were three animals in each group.

of those seen with the homologous LDL. Most importantly, however, in the LDLR ${ }^{-1-}$ mouse (not shown in Table I) the large component of receptor-dependent transport disappeared so that the rates of mouse LDL-C and mhLDL-C uptake into these two organs became essentially identical. It should be emphasized that the derivatization process did not denature, in some manner, the human LDL since splenic uptake of this preparation in both the $\mathrm{LDLR}^{+/+}$and $\mathrm{LDLR}^{-1-}$ animals was similar and occurred at very low rates. Thus, in the mouse it was possible to measure total LDL clearance in the whole animal and in the individual organs using mouse LDL, and then to identify the receptor-independent component of this transport activity using mhLDL.

Fig. 5 summarizes the results of such experiments and shows the microliter of plasma cleared of its LDL-C content per hour by one gram of each tissue. As shown in panel $A$, only two organs manifested high rates of mouse LDL-C transport in the $\mathrm{LDLR}^{+/+}$animals. These included the adrenal gland (517 \pm 178 $\mu \mathrm{l} / \mathrm{h}$ per gram) and liver (266 $\pm 21 \mu \mathrm{l} / \mathrm{h}$ per gram). The spleen, small bowel, lung and colon had much lower rates of uptake (10-26 $\mu \mathrm{l} / \mathrm{h}$ per gram) while all of the remaining organs took up LDL-C at rates of $<10 \mu \mathrm{l} / \mathrm{h}$ per gram. Uptake of LDL-C into the brain was undetectable. In the $\mathrm{LDLR}^{-1-}$ animals, these rates were all considerably lower and essentially equaled those rates found for the uptake of mhLDL-C $(B)$. The clearance of LDL-C by the adrenal gland, for example, decreased from 517 $\mu \mathrm{l} / \mathrm{h}$ per $\mathrm{g}$ in the $\mathrm{LDLR}^{+/+}$mouse to only $10 \pm 3 \mu \mathrm{l} / \mathrm{h}$ per gram 

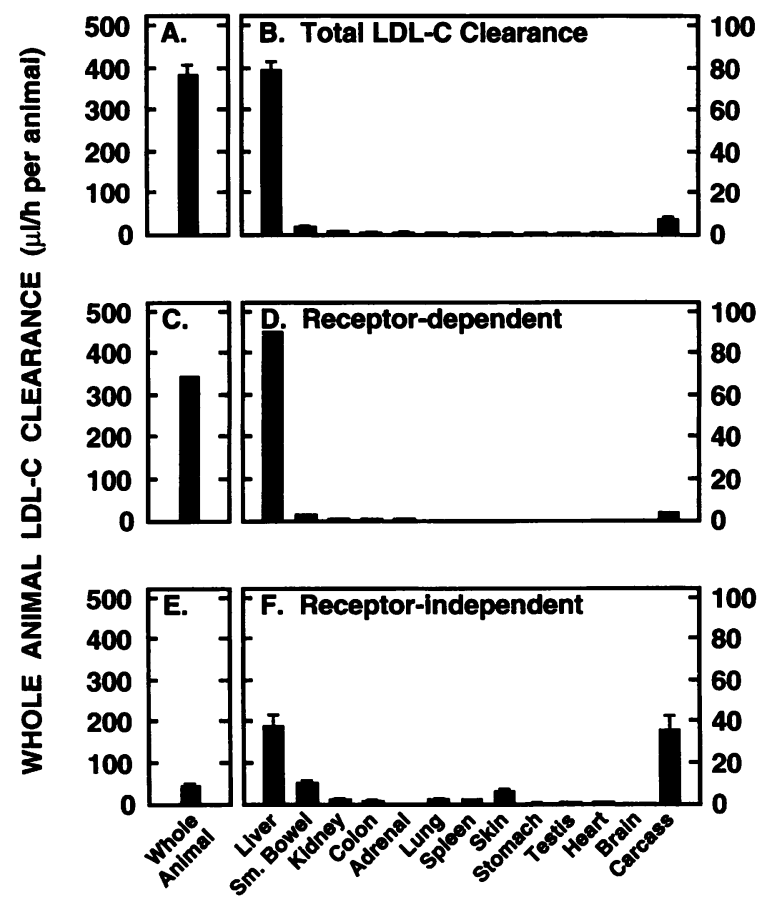

Figure 6. Distribution of total, receptor-dependent, and receptor-independent LDL-C clearance activity in the male $\mathrm{LDLR}^{+/+}$mouse. The data in the upper panels represent mean values \pm 1 SEM for total LDL$C$ clearance in 10 animals $(A)$ and the distribution of this activity in the various tissues $(B)$. The data in the lower panels show the mean values \pm 1 SEM for the rate of receptor-independent clearance in 15 LDLR $^{+/+}$and LDLR $^{-1-}$ animals $(E)$ and the distribution of this activity in the various tissues $(F)$. These latter values were subtracted from the respective values in $A$ and $B$ for total LDL-C transport to give the rates and distribution of receptor-dependent clearance shown in $C$ and $D$.

in the $\mathrm{LDLR}^{-1-}$ animal, while the rate of mhLDL-C uptake in this organ equaled $8 \pm 1$ and $9 \pm 1 \mu \mathrm{l} / \mathrm{h}$ per gram, respectively, in the $\mathrm{LDLR}^{+1+}$ and $\mathrm{LDLR}^{-1-}$ animals $(B)$. Similar findings were observed in the liver. Thus, in these two organs $\sim 98 \%$ of the high rates of LDL-C uptake seen in the $\mathrm{LDLR}^{+/+}$animals were dependent upon the LDL receptor. In other organs, including the spleen and different parts of the gastrointestinal tract, about half of the uptake observed was receptor dependent, although these rates were very low compared with those seen in the adrenal gland and liver. As is apparent in Fig. $5 B$, all tissues except the brain exhibited some receptor-independent LDL-C uptake, but, with the exception of the spleen, lung and small bowel, these rates were all $<9 \mu \mathrm{l} / \mathrm{h}$ per gram.

From these data the absolute rates of LDL-C turnover and the importance of each organ to this process could be determined. As shown in Fig. $6 \mathrm{~A}$, homologous LDL-C was cleared by the whole $\mathrm{LDLR}^{+1+}$ animals at the rate of $386 \pm 25 \mu \mathrm{l} /$ h. The receptor-independent component of this total LDL-C clearance equaled $46 \pm 4 \mu \mathrm{l} / \mathrm{h}$ (Fig. $6 E$ ). When these clearance rates are expressed as a fraction of the plasma volume in these same groups of animals they correspond to fractional catabolic rates of 7.1 and 0.88 pools/day, respectively, and half-lives of 2.3 and $18.9 \mathrm{~h}$, respectively. Thus, in the normal mouse about $88 \%$ of total LDL-C turnover is mediated by the LDL receptor while $12 \%$ is receptor-independent. The distribution of this total LDL-C transport activity is shown in panel B. Clearly one organ, the liver, accounted for $79 \%$ of total LDL-C degradation while the small bowel (4\%) and the other extrahepatic organs (17\%) accounted for the remainder. Fig. 6 also shows the distribution of the receptor-dependent $(D)$ and receptor-independent $(F)$ components of this transport activity. The $\mathrm{LDLR}^{+/+}$animal cleared LDL-C through the LDLR at a rate of $340 \mu \mathrm{l} / \mathrm{h}(C)$, and $91 \%$ of this receptor-dependent uptake was located in the liver $(D)$. In contrast, LDL-C was cleared by the receptorindependent process at a rate of $46 \pm 4 \mu \mathrm{l} / \mathrm{h}(E)$ and only $38 \%$ of this activity was located in the liver $(F)$. These studies also demonstrated that the absolute rate of receptor-independent LDL transport and the tissue distribution of this activity was the same in the $\mathrm{LDLR}^{+1+}$ and $\mathrm{LDLR}^{-1-}$ animals.

\section{Discussion}

These studies provide detailed rate constants in the mouse for those processes that dictate cholesterol balance across the individual organs and the whole animal, and, in addition, they illustrate in quantitative terms the role of the LDL receptor in this balance. These rate constants are summarized in Fig. 7 where the numbers represent the synthesis or net flux of sterol expressed as $\mathrm{mg}$ of cholesterol per day per $\mathrm{kg}$ body weight. The numbers in the circles are derived for the male $\mathrm{LDLR}^{+/+}$mice, while the numbers adjacent to the circles come from the data in the male $\mathrm{LDLR}^{-1-}$ animals. In this diagram the body has been divided into three functionally distinct groups of organs. The small bowel $(A)$ is the site of entry of dietary cholesterol into the body, and this sterol is carried to the liver in the chylomicron particle. Cholesterol from the other extrahepatic tissues $(B)$ also must be transported to the liver, but this process presumably is mediated by high density lipoproteins (HDL) (59). The liver $(C)$ plays the central role in maintaining cholesterol homeostasis in the animal as well as in dictating the steadystate levels of LDL-C in the plasma (23).

The animals in these studies were fed to steady-state conditions using low cholesterol rodent diet where the dietary sterol intake equaled $\sim 40 \mathrm{mg} / \mathrm{d}$ per $\mathrm{kg}$. The exact percentages of this dietary intake that were absorbed into the body or remained in the intestinal lumen were not measured in these studies. Under these conditions the rate of cholesterol synthesis in the whole animal was not significantly different in the two experimental groups and equaled 153 and $162 \mathrm{mg} / \mathrm{d}$ per $\mathrm{kg}$ in the $\mathrm{LDLR}^{+1+}$ and $\mathrm{LDLR}^{-1-}$ animals, respectively (Fig. 4). Thus, dietary cholesterol intake equaled $\sim 26 \%$ of the daily synthesis rate. This percentage is about half of that seen in similar recent studies in cynomolgus monkey $(54 \%)$ or routinely encountered in human studies (40-60\%) (49). Of this whole animal cholesterol synthesis in the LDLR $^{+/+}$animals, 66\% $(101 \mathrm{mg} / \mathrm{d}$ per $\mathrm{kg}$ ) occurred in the extrahepatic tissues (Fig. 4) that made up $91 \%$ of the body mass, while the liver and small bowel accounted for only $22 \%$ (34 mg/d per kg) and $12 \%(18 \mathrm{mg} / \mathrm{d}$ per $\mathrm{kg}$ ), respectively. Not only was the rate of cholesterol synthesis in the $\mathrm{LDLR}^{-1-}$ mice the same as in the control animals, but the percentage distribution of this synthetic activity in the three major tissue compartments was also virtually identical (Fig. 7). Thus, total deletion of LDL receptor activity had no effect on the rates of cholesterol synthesis in the whole animal (Fig. 4), in the major tissue compartments (Fig. 7), or in the individual organs (Fig. 3,4). Similar results have been reported in rabbits that are homozygous for loss of functional receptor activity except that in the $\mathrm{LDLR}^{-1-}$ members in this species 


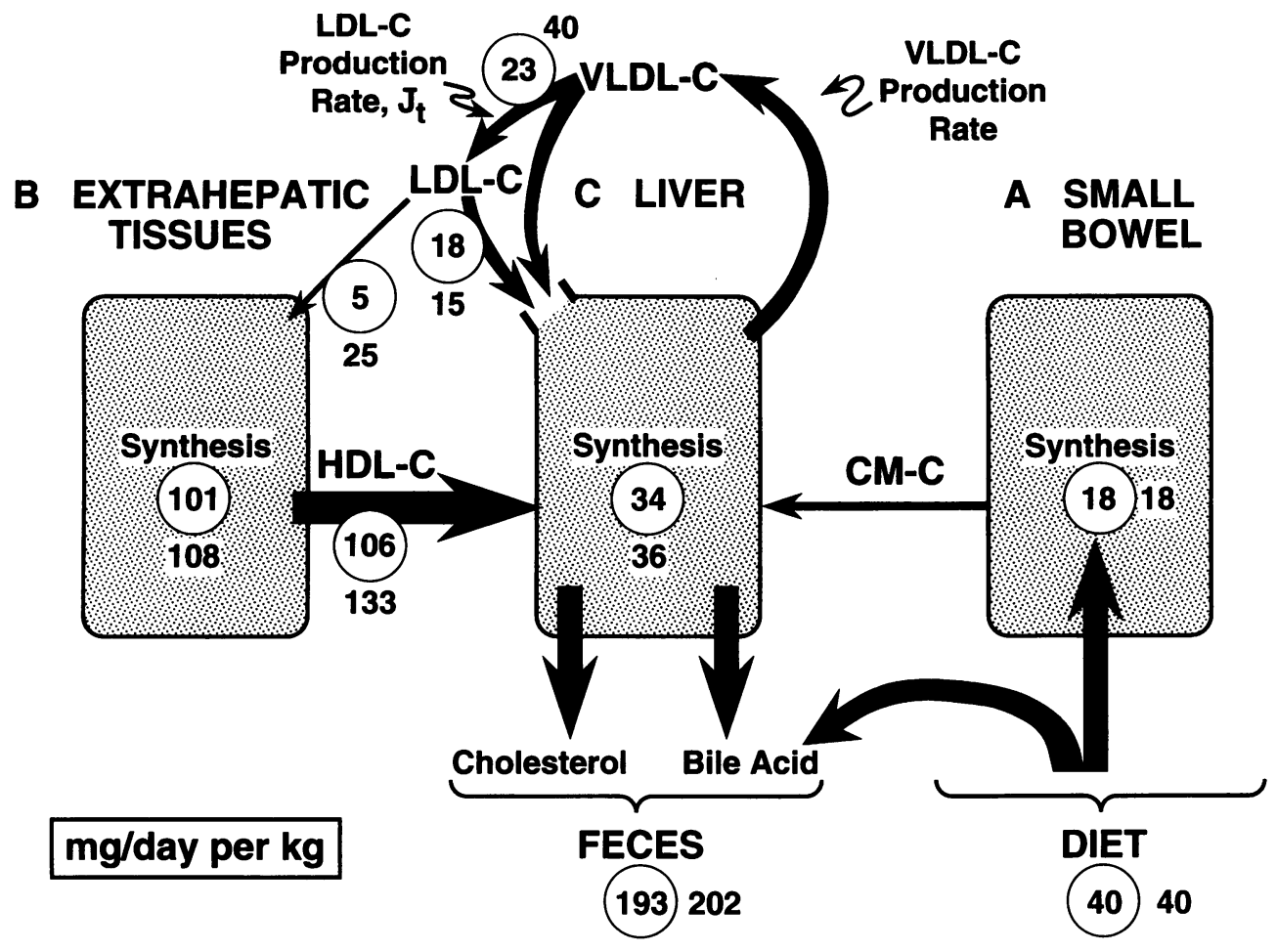

Figure 7. Summary of the rates of cholesterol synthesis and net flux across the major organs in the male $\mathrm{LDLR}^{+1+}$ and $\mathrm{LDLR}^{-1-}$ mice. All numbers represent $\mathrm{mg}$ of cholesterol per day normalized to a constant body weight of $1 \mathrm{~kg}$. The values in the circles come from the measurements made in the LDLR $^{+1+}$ animals while the numbers adjacent to the circles are the values found in the $\mathrm{LDLR}^{-1-}$ mice. there was a $40 \%$ decrease in the rate of hepatic sterol synthesis $(58)$.

Under these conditions where the net flow of cholesterol across both types of animals from synthesis and diet equaled $\sim 200 \mathrm{mg} / \mathrm{d}$ per $\mathrm{kg}$, there were significant differences in the LDL-C production rate; $J_{t}$ equaled $23 \mathrm{mg} / \mathrm{d}$ per $\mathrm{kg}$ in the $\mathrm{LDLR}^{+1+}$ mice but was 1.7 -fold higher in the $\mathrm{LDLR}^{-1-}$ animals ( $40 \mathrm{mg} / \mathrm{d}$ per $\mathrm{kg}$ ). In the normal animals, $79 \%(18 \mathrm{mg} / \mathrm{d}$ per $\mathrm{kg}$ ) of this LDL-C was returned to the liver, and this occurred overwhelmingly through receptor-dependent transport (Figs. 5 and 6). Only $21 \%(5 \mathrm{mg} / \mathrm{d}$ per $\mathrm{kg}$ ) was taken up by all of the extrahepatic organs, and this occurred primarily through receptor-independent transport (Fig. 6). However, in the LDLR $^{-1-}$ animals, of the $40 \mathrm{mg} / \mathrm{d}$ per $\mathrm{kg}$ of LDL-C produced, only $38 \%$ ( $15 \mathrm{mg} / \mathrm{d}$ per $\mathrm{kg}$ ) were returned to the liver while $62 \%$ ( $25 \mathrm{mg} / \mathrm{d}$ per $\mathrm{kg}$ ) was taken up by the extrahepatic tissues: in both cases this occurred solely through receptor-independent LDL-C transport. As a consequence, the steady-state concentration of LDL-C in the plasma equaled $7 \mathrm{mg} / \mathrm{dl}$ in the normal animals and $101 \mathrm{mg} / \mathrm{dl}$ in the animals lacking functional LDL receptor activity (Fig. 1). In addition, because of the increased delivery of LDL-C to the extrahepatic tissues, the amount of sterol that had to be carried, presumably in HDL, through the plasma to the liver increased from 106 to $133 \mathrm{mg} /$ day per $\mathrm{kg}$ in the $\mathrm{LDLR}^{-1-}$ animals. This latter change presumably accounted for the fact that the HDL-C concentration was also elevated in the receptor deficient animals (Fig. 1).

These quantitative data provide the basis for five major conclusions concerning cholesterol and LDL-C metabolism in the mouse. First, as expected, the absolute rates of cholesterol synthesis and LDL-C clearance were much higher in this species than in larger animal models and humans. Whole body sterol synthesis, for example, equaled $\sim 150 \mathrm{mg} / \mathrm{d}$ per $\mathrm{kg}$ in these mice compared to the rates observed in larger animals like hamsters $(\sim 30 \mathrm{mg} / \mathrm{d}$ per $\mathrm{kg})$, various monkeys $(10-25 \mathrm{mg} /$ $\mathrm{d}$ per $\mathrm{kg}$ ), and humans $(8-10 \mathrm{mg} / \mathrm{d}$ per $\mathrm{kg})$. Nevertheless, in the mouse, as in the hamster, cynomolgus monkey, and, probably, human, the great majority of this synthetic activity was found in the extrahepatic organs and not in the liver (23). Similarly, the absolute rate of LDL-C clearance from the plasma was very high in the mouse $(\sim 14 \mathrm{ml} / \mathrm{h}$ per $\mathrm{kg})$ compared to that found in hamsters ( $\sim 6 \mathrm{ml} / \mathrm{h}$ per $\mathrm{kg})$, cynomolgus monkeys $(\sim 1.5 \mathrm{ml} / \mathrm{h}$ per $\mathrm{kg})$, and humans $(\sim 0.7 \mathrm{ml} / \mathrm{h}$ per $\mathrm{kg})$. Yet, as in all of these species, the liver accounted for the great majority of this clearance, and $>90 \%$ of this hepatic uptake in the $\mathrm{LDLR}^{+/+}$animals was mediated by the LDL receptor (Fig. $6)$. Thus, while the mouse manifested the very high rates of sterol turnover and LDL-C clearance that would be anticipated in such a metabolically active, small animal, the relative importance of the liver to whole animal cholesterol synthesis $(\sim 22 \%)$ and LDL-C degradation $(\sim 80 \%)$ was virtually identical to the relative importance of this organ in animals like the hamster and cynomolgus monkey $(23,49)$.

Second, the relative importance of the two mechanisms for LDL-C clearance from the plasma, i.e., receptor-dependent and receptor-independent transport are, however, somewhat different in the mouse compared to larger animals. This difference arises from the fact that receptor-dependent transport varies to a greater extent with the size of the animal than does the receptorindependent component. For example, the rate of receptor-independent LDL-C clearance increases only sixfold, from $\sim 0.3$ $\mathrm{ml} / \mathrm{h}$ per $\mathrm{kg}$, to $\sim 1.8 \mathrm{ml} / \mathrm{h}$ per $\mathrm{kg}$ in observations made in humans, non-human primates, rabbits, hamsters and mice. In contrast, in these same species, receptor-dependent LDL-C uptake increases nearly 30 -fold, from $0.4 \mathrm{ml} / \mathrm{h}$ per $\mathrm{kg}$ to $12.0 \mathrm{ml} /$ $\mathrm{h}$ per kg. Thus, while the LDL receptor accounts for $88 \%$ of LDL-C degradation in these studies in the mouse, this percentage is lower in larger animals like the hamster (73\%), rabbit 
$(72 \%)$, and human $(58 \%)$. Despite this relative difference, however, the distribution of receptor-dependent and receptorindependent transport activity is virtually the same in the mouse as in all other species in which such data are available. Nearly all receptor-dependent transport activity is located in the liver while the majority of receptor-independent LDL-C clearance takes place in the extrahepatic organs. Any genetic or environmental factor, therefore, that suppresses hepatic LDL receptor activity forces more LDL-C into the peripheral organs.

Third, these studies also demonstrate that there is relatively little difference in sterol and lipoprotein metabolism in the male and female animals. In particular, in contrast to the hamster and rat, hepatic cholesterol synthesis is similar in the two sexes of this strain as it is in most of the other organs (Fig. 3). The most striking difference observed was in the adrenal gland where the female animals had cholesterol concentrations that were fourfold higher than in the male (Fig. 2), and rates of cholesterol synthesis that were nearly twofold greater (Fig. 3). Nevertheless, the similarities in rates of hepatic sterol synthesis and in the levels of the various of lipoproteins (Fig. 1) suggest that either sex may be used for studying regulation of hepatic LDL receptor activity. This situation is quite different from that seen in the rat and hamster where the male and female animals respond very differently to dietary and pharmacological challenges.

Fourth, these studies reemphasize the importance of the LDL receptor for controlling the circulating plasma LDL-C concentration but identify a unique feature of this process that is evident in the mouse. The steady-state LDL-C concentration is determined in a major way by both the magnitude of receptordependent transport, $J^{\mathrm{m}}$, and the rate of LDL-C production, $J_{\mathrm{t}}$. It has been calculated that loss of all LDLR activity in the rabbit or human would raise the plasma LDL-C concentration to only $100-200 \mathrm{mg} / \mathrm{dl}$ provided that the rate of LDL-C production remained constant (43). However, with loss of hepatic receptor activity a larger proportion of the apoE/apoB100-containing VLDL remnants in these two species is converted to LDL-C so that the LDL-C production rate increases threefold in the human and sixfold in the rabbit $(38,43)$. Thus, the reason that the steady-state LDL-C concentration reaches $400-600 \mathrm{mg} / \mathrm{dl}$ in these two species when all LDLR activity is lost is because $J_{t}$ increases 3-6-fold as $J^{\mathrm{m}}$ approaches zero. The mouse differs from these species in two ways. First, in contrast to the very high absolute rates of sterol synthesis and receptor-dependent transport observed in the $\mathrm{LDLR}^{+/+}$animals, the absolute rate of LDL-C production ( $23 \mathrm{mg} / \mathrm{d}$ per $\mathrm{kg}$ ) was barely higher than the rates found in cynomolgus monkey $(17 \mathrm{mg} / \mathrm{d}$ per $\mathrm{kg}$ ) and humans ( $13 \mathrm{mg} / \mathrm{d}$ per $\mathrm{kg}$ ) (49). Second, with total loss of LDLR activity, $J_{t}$ in the mouse increases only 1.7 -fold (Fig. 7) compared with 3-6-fold in the human and rabbit. Presumably, these differences reflect the fact that in the mouse a large portion of the VLDL that is synthesized by the liver contains apoB48, and so the remnants of these particles might be cleared from the plasma by LRP. Furthermore, when LDL receptor activity in the liver is lost, the increase in $J_{t}$ is muted. Thus, in the LDLR $^{+/+}$mouse (and, probably, the rat), the steady-state LDLC level is only about $7 \mathrm{mg} / \mathrm{dl}$ and this value increases to only $\sim 100 \mathrm{mg} / \mathrm{dl}$ with total loss of receptor activity. These findings emphasize the important fact that the LDL-C production rate term plays a major role in determining the plasma LDL-C concentration. Any genetic polymorphism, or dietary or pharmacological manipulation, that alters the relative affinity of the rem- nants of the VLDL particle for the LDLR or, possibly, LRP can profoundly alter the steady-state LDL-C concentration even under circumstances where hepatic LDL receptor activity, $J^{\mathrm{m}}$, remains essentially constant.

Finally, in contrast to the important role of the LDL receptor in regulating the plasma LDL-C concentration, this study also provides further support for the concept that receptor-dependent LDL-C transport plays little or no role in maintaining the functional integrity of the extrahepatic organs. With the exception of the adrenal gland, almost no LDL-C was taken up by this mechanism by any of the extrahepatic tissues (Fig. 5). Furthermore, in the absence of the LDLR, the mice grew normally and their organs attained the same sizes as in the $\operatorname{LDLR}^{+/+}$animals. Most importantly, all of the organs in the receptor deficient animals maintained the same concentrations of cholesterol (Fig. 2 ) as found in the control mice. Thus, these findings further support the concept that dietary or pharmacological manipulations that increase hepatic LDL receptor activity and lower the steady-state LDL-C concentration should have no detrimental effects on the normal physiological function of any extrahepatic organ.

\section{Acknowledgments}

The authors express their appreciation to Jeff Graven, Mark Herndon, Lucy Lundquist, Stephen Ostermann, and Monti Schneiderman for their excellent technical assistance in carrying out these studies and Marty Parkey for her help in preparation of the manuscript.

This work was supported, in part, by National Institutes of Health Research grants HL-09610 and HL-20948 and by grants from the Moss Heart Fund, the Perot Family Foundation and the Keck Foundation. J. Herz is supported by the Syntex Scholar Program and is a Lucille P. Markey Scholar.

\section{References}

1. Mahley, R. W., and L. Innerarity. 1983. Lipoprotein receptors and cholesterol homeostasis. Biochim. Biophys. Acta. 737:197-222.

2. Havel, R. J. 1986. Functional activities of hepatic lipoprotein receptors. Ann. Rev. Physiol. 48:119-134.

3. Kane, J. P., D. A. Hardman, and H. E. Paulus. 1980. Heterogeneity of apolipoprotein B: Isolation of a new species from human chylomicrons. Proc. Natl. Acad. Sci. USA. 77:2465-2469.

4. Krishnaiah, K. V., L. F. Walker, J. Borensztajn, G. Schonfeld, and G. S. Getz. 1980. Apolipoprotein B variant derived from rat intestine. Proc. Natl. Acad. Sci. USA. 77:3806-3810.

5. Innerarity, T. L., S. G. Young, K. S. Poksay, R. W. Mahley, R. S. Smith, R. W. Milne, Y. L. Marcel, and K. H. Weisgraber. 1987. Structural relationship of human apolipoprotein B48 to apolipoprotein B100. J. Clin. Invest. 80:17941798.

6. Chan, L. 1992. Apolipoprotein B, the major protein component of triglyceride-rich and low density lipoproteins. J. Biol. Chem. 267:25621-25624.

7. Elovson, J., Y. O. Huang, N. Baker, and R. Kannan. 1981. Apolipoprotein B is structurally and metabolically heterogeneous in the rat. Proc. Natl. Acad. Sci. USA. 78:157-161

8. Demmer, L. A., M. S. Levin, J. Elovson, M. A. Reuben, A. J. Lusis, and J. I. Gordon. 1986. Tissue-specific expression and developmental regulation of the rat apolipoprotein B gene. Proc. Natl. Acad. Sci. USA. 83:8102-8106.

9. Scott, J. 1989. The molecular and cell biology of apolipoprotein-B. Mol. Biol. Med. 6:65-80.

10. Higuchi, K., K. Kitagawa, K. Kogishi, and T. Takeda. 1992. Developmental and age-related changes in apolipoprotein B mRNA editing in mice. $J$. Lipid Res. 33:1753-1764.

11. Kita, T., J. L. Goldstein, M. S. Brown, Y. Watanabe, C. A. Hornick, and R. J. Havel. 1982. Hepatic uptake of chylomicron remnants in WHHL rabbits: a mechanism genetically distinct from the low density lipoprotein receptor. Proc. Natl. Acad. Sci. USA. 79:3623-3627.

12. Rubinsztein, D. C., J. C. Cohen, G. M. Berger, D. R. van der Westhuyzen, G. A. Coetzee, and W. Gevers. 1990. Chylomicron remnant clearance from the 
plasma is normal in familial hypercholesterolemic homozygotes with defined receptor defects. J. Clin. Invest. 86:1306-1312.

13. Herz, J., U. Hamann, S. Rogne, O. Myklebost, H. Gausepohl, and K. K. Stanley. 1988. Surface location and high affinity for calcium of a 500 -kd liver membrane protein closely related to the LDL-receptor suggest a physiological role as lipoprotein receptor. EMBO (Eur. Mol. Biol. Organ.) J. 7:4119-4127.

14. Kowal, R. C., J. Herz, K. H. Weisgraber, R. W. Mahley, M. S. Brown, and J. L. Goldstein. 1990. Opposing effects of apolipoproteins $\mathrm{E}$ and $\mathrm{C}$ on lipoprotein binding to low density lipoprotein receptor-related protein. J. Biol. Chem. 265:10771-10779.

15. Brown, M. S., J. Herz, R. C. Kowal, and J. L. Goldstein. 1991. The lowdensity lipoprotein receptor-related protein: double agent or decoy? Curr. Opin. Lipidology. 2:65-72.

16. Kowal, R. C., J. Herz, J. L. Goldstein, V. Esser, and M. S. Brown. 1989. Low density lipoprotein receptor-related protein mediates uptake of cholesteryl esters derived from apoprotein E-enriched lipoproteins. Proc. Natl. Acad. Sci. USA. 86:5810-5814.

17. Strickland, D. K., J. D. Ashcom, S. Williams, W. H. Burgess, M. Migliorini, and W. S. Argraves. 1990. Sequence identity between the $\alpha_{2}$-macroglobulin receptor and low density lipoprotein receptor-related protein suggests that this molecule is a multifunctional receptor. J. Biol. Chem. 265:17401-17404.

18. Beisiegel, U., W. Weber, and G. Bengtsson-Olivecrona. 1991. Lipoprotein lipase enhances the binding of chylomicrons to low density lipoprotein receptorrelated protein. Proc. Natl. Acad. Sci. USA. 88:8342-8346.

19. Willnow, T. E., J. L. Goldstein, K. Orth, M. S. Brown, and J. Herz. 1992. Low density lipoprotein receptor-related protein and gp330 bind similar ligands, including plasminogen activator-inhibitor complexes and lactoferrin, an inhibitor of chylomicron remnant clearance. J. Biol. Chem. 267:26172-26180.

20. Willnow, T. E., Z. Sheng, S. Ishibashi, and J. Herz. 1994. Inhibition of hepatic chylomicron remnant uptake by viral gene transfer. Science (Wash. DC). 264:1471-1474.

21. Sherrill, B. C., and J. M. Dietschy. 1978. Characterization of the sinusoidal transport process responsible for uptake of chylomicrons by the liver. J. Biol. Chem. 253:1859-1867.

22. Yamamoto, T., C. G. Davis, M. S. Brown, W. J. Schneider, M. Linette Casey, J. L. Goldstein, and D. W. Russell. 1984. The human LDL receptor: a cysteine-rich protein with multiple Alu sequences in its mRNA. Cell. 39:27-38.

23. Dietschy, J. M., S. D. Turley, and D. K. Spady. 1993. Role of liver in the maintenance of cholesterol and low density lipoprotein homeostasis in different animal species, including humans. J. Lipid Res. 34:1637-1659.

24. Kita, T., M. S. Brown, D. W. Bilheimer, and J. L. Goldstein. 1982. Delayed clearance of very low density and intermediate density lipoproteins with enhanced conversion to low density lipoprotein in WHHL rabbits. Proc. Natl. Acad. Sci. USA. 79:5693-5697.

25. Yamada, N., D. M. Shames, J. B. Stoudemire, and R. J. Havel. 1986. Metabolism of lipoproteins containing apolipoprotein B-100 in blood plasma of rabbits: Heterogeneity related to the presence of apolipoprotein E. Proc. Natl. Acad. Sci. USA. 83:3479-3483.

26. Kovanen, P. T., D. W. Bilheimer, J. L. Goldstein, J. J. Jaramillo, and M. S. Brown. 1981. Regulatory role for hepatic low density lipoprotein receptors in vivo in the dog. Proc. Natl. Acad. Sci. USA. 78:1194-1198.

27. Ishibashi, S., M. S. Brown, J. L. Goldstein, R. D. Gerard, R. E. Hammer, and J. Herz. 1993. Hypercholesterolemia in low density lipoprotein receptor knockout mice and its reversal by adenovirus-mediated gene delivery. J. Clin. Invest. 92:883-893.

28. Kane, J. P. 1983. Apolipoprotein B: structural and metabolic heterogeneity. Ann. Rev. Physiol. 45:637-650.

29. Lipid Research Clinics Program. 1984. The Lipid Research Clinics coronary primary prevention trial results. I. Reduction in incidence of coronary heart disease. JAMA. 251:351-364.

30. Holme, I. 1990. An analysis of randomized trials evaluating the effect of cholesterol reduction on total mortality and coronary heart disease incidence. Circulation. 82:1916-1924.

31. PDAY Research Group. 1993. Natural history of aortic and coronary atherosclerotic lesions in youth. Findings from the PDAY study. Arterioscler. Thromb. 13:1291-1298.

32. Chen, Z., R. Peto, R. Collins, S. MacMahon, J. Lu, and W. Li. 1991. Serum cholesterol concentration and coronary heart disease in population with low cholesterol concentrations. Br. Med. J. 303:276-282.

33. Spady, D. K., J. B. Meddings, and J. M. Dietschy. 1986. Kinetic constants for receptor-dependent and receptor-independent low density lipoprotein transport in the tissues of the rat and hamster. J. Clin. Invest. 77:1474-1481.

34. Meddings, J. B., and J. M. Dietschy. 1987. Regulation of plasma low density lipoprotein levels: New strategies for drug design. In Progress in Clinical Biochemistry and Medicine, Volume 5. Springer-Verlag, Berlin. 1-24.

35. Spady, D. K., D. W. Bilheimer, and J. M. Dietschy. 1983. Rates of receptor-dependent and -independent low density lipoprotein uptake in the hamster. Proc. Natl. Acad. Sci. USA. 80:3499-3503.

36. Spady, D. K., S. D. Turley, and J. M. Dietschy. 1985. Receptor-independent low density lipoprotein transport in the rat in vivo. Quantitation, characterization, and metabolic consequences. J. Clin. Invest. 76:1113-1122.

37. Bilheimer, D. W., J. L. Goldstein, S. M. Grundy, T. E. Starzl, and M. S. Brown. 1984. Liver transplantation to provide low-density-lipoprotein receptors and lower plasma cholesterol in a child with homozygous familial hypercholesterolemia. N. Engl. J. Med. 311:1658-1664.

38. Spady, D. K., M. Huettinger, D. W. Bilheimer, and J. M. Dietschy. 1987. Role of receptor-independent low density lipoprotein transport in the maintenance of tissue cholesterol balance in the normal and WHHL rabbit. J. Lipid Res. 28:3241.

39. Bilheimer, D. W., N. J. Stone, and S. M. Grundy. 1979. Metabolic studies in familial hypercholesterolemia. Evidence for a gene-dosage effect in vivo. $J$. Clin. Invest. 64:524-533.

40. Vega, G. L., and S. M. Grundy. 1986. In vivo evidence for reduced binding of low density lipoproteins to receptors as a cause of primary moderate hypercholesterolemia. J. Clin. Invest. 78:1410-1414.

41. Innerarity, T. L., K. H. Weisgraber, K. S. Arnold, R. W. Mahley, R. M. Krauss, G. L. Vega, and S. M. Grundy. 1987. Familial defective apolipoprotein B-100: Low density lipoproteins with abnormal receptor binding. Proc. Natl. Acad. Sci. USA. 84:6919-6923.

42. Miserez, A. R., R. Laager, N. Chiodetti, and U. Keller. 1994. High prevalence of familial defective apolipoprotein B-100 in Switzerland. J. Lipid Res. 35:574-583.

43. Meddings, J. B., and J. M. Dietschy. 1986. Regulation of plasma levels of low-density lipoprotein cholesterol: interpretation of data on low-density lipoprotein turnover in man. Circulation. 74:805-814.

44. Spady, D. K., and J. M. Dietschy. 1985. Dietary saturated triacylglycerols suppress hepatic low density lipoprotein receptor activity in the hamster. Proc. Natl. Acad. Sci. USA. 82:4526-4530.

45. Woollett, L. A., D. K. Spady, and J. M. Dietschy. 1992. Regulatory effects of the saturated fatty acids 6:0 through 18:0 on hepatic low density lipoprotein receptor activity in the hamster. J. Clin. Invest. 89:1133-1141.

46. Daumerie, C. M., L. A. Woollett, and J. M. Dietschy. 1992. Fatty acids regulate hepatic low density lipoprotein receptor activity through redistribution of intracellular cholesterol pools. Proc. Natl. Acad. Sci. USA. 89:10797-10801.

47. Turley, S. D., B. P. Daggy, and J. M. Dietschy. 1994. Psyllium augments the plasma cholesterol lowering action of cholestyramine in the hamster by enhancing net sterol loss from the liver. Gastroenterology. 107:444-452.

48. Woollett, L. A., D. K. Spady, and J. M. Dietschy. 1992. Saturated and unsaturated fatty acids independently regulate low density lipoprotein receptor activity and production rate. J. Lipid Res. 33:77-88.

49. Turley, S. D., D. K. Spady, and J. M. Dietschy. 1994. Role of liver in the synthesis of cholesterol and the clearance of low density lipoproteins in the cynomolgus monkey. J. Lipid Res. In press.

50. Andersen, J. M., and J. M. Dietschy. 1978. Relative importance of high and low density lipoproteins in the regulation of cholesterol synthesis in the adrenal gland, ovary, and testis of the rat. J. Biol. Chem. 253:9024-9032.

51. Spady, D. K., and J. M. Dietschy. 1983. Sterol synthesis in vivo in 18 tissues of the squirrel monkey, guinea pig, rabbit, hamster, and rat. J. Lipid Res. 24:303-315.

52. Dietschy, J. M., and D. K. Spady. 1984. Measurement of rates of cholesterol synthesis using tritiated water. J. Lipid Res. 25:1469-1476.

53. Turley, S. D., J. M. Andersen, and J. M. Dietschy. 1981. Rates of sterol synthesis and uptake in the major organs of the rat in vivo. J. Lipid Res. 22:551569.

54. Glass, C. K., R. C. Pittman, G. A. Keller, and D. Steinberg. 1983. Tissue sites of degradation of apoprotein A-I in the rat. J. Biol. Chem. 258:7161-7167.

55. Weisgraber, K. H., T. L. Innerarity, and R. W. Mahley. 1978. Role of the lysine residues of plasma lipoproteins in high affinity binding to cell surface receptors on human fibroblasts. J. Biol. Chem. 253:9053-9062.

56. Mahley, R. W., K. H. Weisgraber, G. W. Melchior, T. L. Innerarity, and K. S. Holcombe. 1980. Inhibition of receptor-mediated clearance of lysine and arginine-modified lipoproteins from the plasma of rats and monkeys. Proc. Natl. Acad. Sci. USA. 77:225-229.

57. Bill, A., G. Herbai, and S. Westman-Naeser. 1971. Red blood cell and plasma volumes, total body water and sulfate space in obese-hyperglycemic mice and lean litter mates. Acta Physiol. Scand. 82:470-476.

58. Dietschy, J. M., T. Kita, K. E. Suckling, J. L. Goldstein, and M. S. Brown. 1983. Cholesterol synthesis in vivo and in vitro in the WHHL rabbit, an animal with defective low density lipoprotein receptors. J. Lipid Res. 24:469-480.

59. Johnson, W. J., F. H. Mahlberg, G. H. Rothblat, and M. C. Phillips. 1991. Cholesterol transport between cells and high-density lipoproteins. Biochim. Biophys. Acta. 1085:273-298. 